\title{
The Effect of Unilateral Endometrioma Excision on Ovarian Reserve
}

\author{
Unilateral Endometrioma Eksizyonunun \\ Over Rezervi Üzerine Etkisi
}

\section{Saime SEMIZ, ${ }^{a}$ \\ Murat API, ${ }^{b}$ \\ Semra KAYATAŞ, \\ Ayşen $\mathrm{BOZA}^{\mathrm{C}}$}

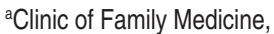

Adana Numune Training and

Research Hospital,

Adana

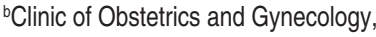
Zeynep Kamil Women and Children's Training and Research Hospital, ${ }^{c} \mathrm{Clinic}$ of Obstetrics and Gynecology, Göztepe Training and Research Hospital, İstanbul

Geliş Tarihi/Received: 06.07 .2014 Kabul Tarihi/Accepted: 25.02.2015

Yazıșma Adresi/Correspondence: Ayşen BOZA

Göztepe Training and Research Hospital, Clinic of Obstetrics and Gynecology, İstanbul

TÜRKIYE/TURKEY

\begin{abstract}
Objective: To evaluate the effect of laparoscopic cystectomy for endometriomas on ovarian reserve as determined by antral follicle count (AFC) and follicle stimulating hormone (FSH) level. Material and Methods: In this prospective, observational, operated and non-operated site comparative study, twenty one women between 20-36 ages with previous history of laparoscopic surgery for unilateral ovarian endometriomas greater than $30 \mathrm{~mm}$ were called for the evaluation of ovarian reserve at third month. Only first endometrioma removal operations were included. Removal of endometrioma was performed by laparoscopic ovarian tissue-sparing stripping technique. AFC of both ovaries were evaluated on 2-5 day of postoperative third menstrual cycle by independent examiners, blinded to the clinical and surgical history of patients. AFCs of both ovaries were analyzed to compare between operated and non-operated sites. Pre and postoperative FSH levels were recorded also. Results: There was statistically significant difference in the mean number of antral follicles in the operated side ovary $(2.61 \pm 1.24)$ when compared to the non-operated side ovary $(4.23 \pm 0.88)(\mathrm{p}<0.001)$. Although a significant difference was found between pre and postoperative FSH levels $(6.7 \pm 1.8$ vs $6.9 \pm 1.6, p=0.011)$, this did not reach to clinical significance. Conclusion: Our study results suggested that excision of endometriomas might have a negative impact on ovarian reserve as evidenced by a significant postoperative fall in ipsilateral AFC level.
\end{abstract}

Key Words: Endometriosis; laparoscopy; follicle stimulating hormone; follicular fluid

ÖZET Amaç: Endometriyoma eksizyonu için yapılan laparoskopik kistektominin over rezervi üzerine etkilerinin antral folikül sayısı (AFS) ve folikül stimülan hormon (FSH) seviyesi açısından değerlendirilmesi. Gereç ve Yöntemler: Prospektif, gözlemsel, opere edilen tarafın opere edilmeyen tarafla karşılaştırıldığı bu çalışmada tek taraflı, $30 \mathrm{~mm}$ üzerinde ovarian endometriyoma nedeniyle laparoskopik operasyon geçirme öyküsü olan 20-36 yaş arası 21 kadın, operasyon sonrası 3. ayda çağrıldı. Sadece ilk kez ve laparoskopik stripping yöntemiyle endometriyoma ameliyatı geçirenler çalışmaya dâhil edildi. Her iki overin antral folikülleri, hastanın klinik ve operasyon öyküsüne kör bağımsız bir araştırmacı tarafından operasyon sonrası 3. ayda siklusun 2-5. günleri arası değerlendirildi. Her iki overin AFS'leri opere olan ve olmayan taraf arasında karşılaştırıldı. Pre ve postoperative FSH düzeyleri kaydedildi. Bulgular: Opere olan ve olmayan taraf kıyaslandığında ortalama antral folikülleri arasında istatistiksel olarak anlamlı bir fark bulunmaktadır $(2,61 \pm 1,24$ ve $4,23 \pm 0,88$, sirasiyla) $(\mathrm{p}<0,001)$. Pre ve postoperatif FSH seviyeleri $(6,7 \pm 1,8$ ve $6,9 \pm 1,6, \mathrm{p}=0,011)$ arasinda da önemli bir fark olmasına rağmen, bu fark klinik olarak anlamlı değildir. Sonuç: Çalışmamızın sonuçları postoperatif cerrahi tarafindaki AFS seviyelerinde anlamlı bir azalmayı işaret ettiğinden endometriyoma eksizyonunun over rezervi üzerine negatif bir etki yapabilecegini ortaya koymaktadır.

Anahtar Kelimeler: Endometriyoz; laparoskopi; folikül stimüle edici hormon; folliküler sıvı

Turkiye Klinikleri J Gynecol Obst 2015;25(2):71-5

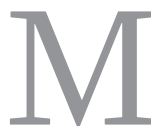
echanisms of infertility associated with endometriosis are controversial. It is hypothesized that endometriosis is associated with overproduction of prostaglandins, metalloproteinases, cytokines, 
and chemokines and that the resulting inflammatory process impairs ovarian, peritoneal, tubal, and endometrial function, leading to defective folliculogenesis, fertilization, and/or implantation. ${ }^{1,2}$ These observations may have detrimental effect on ovarian reserve in patients with endometriosis. Furthermore, excision of endometrioma may also affect the ovarian reserve.

Although laparoscopy was considered as the primary surgical option for the treatment of endometriomas, there is no definitive laparoscopic technique preferred. ${ }^{3}$ The stripping of the pseudo capsule is the most commonly used operative technique. ${ }^{4}$ Fenestration, drainage and coagulation or laser vaporization are the other techniques that have been used. ${ }^{5}$ At laparoscopy, due to greater pain relief and less recurrence rate, the stripping technique has been reported to be preferable to drainage and ablative techniques. ${ }^{6}$ Although the stripping technique is thought to be a most common operative technique which saves future reproductive function and patient's fertility, major concern is the possible loss of follicles might have a negative impact on ovarian reserve and function. ${ }^{7-9}$

Some literature suggested excisional surgery of endometriomas, in particular the stripping technique may cause ovarian trauma as loss of follicles and also loss of ovarian volume. ${ }^{7,10}$ In contrast, Yeung et al. reported advantages of laparoscopic excision of endometrioma by stripping of the cyst wall in terms of pain relief, less recurrence rate and high pregnancy rate. ${ }^{6}$

We designed the present study to assess whether the laparoscopic cystectomy with stripping of ovarian endometrioma was effective on ovarian reserve as determined by ultrasonographic measurement of antral follicle count (AFC) and blood follicle stimulant hormon (FSH) level.

\section{MATERIAL AND METHODS}

Prospective, observational, operated and non-operated site comparative study has been conducted. The study protocol was elaborated according to the revised Declaration of Helsinki and was approved by the local Research and Ethics Committee of our hospital. All subjects were provided written informed consent.

Twenty one, 20-36 years, regularly menstruating women who underwent laparoscopic cystectomy for unilateral ovarian endometriomas greater than to $30 \mathrm{~mm}$ in diameter which verified by histopathologic investigation were included. They were called for the evaluation of ovarian reserve at third month. Women who had previously undergone ovarian surgery or received any medication (gonadotropin releasing hormone antagonist or oral contraceptive drugs) for endometriosis pre or postoperatively, were not included in the study. Only first endometrioma removal operations were included.

All endometriotic cysts were removed by laparoscopic ovarian tissue-sparing stripping technique and entire cyst was enucleated by appliying traction-countertraction technique by the same operator. Hemostasis was achived by suturing with polyglactin 910 suture (2-0 Vicryl) and cyst bed was not coagulated by electrical energy, bleeding from ovarian hilus was resolved only by suturing. There was no hematoma related to suturing.

All patients who had a laparoscopic cystectomy were called for vaginal ultrasound examination on 2-5 days of follicular phase of the third postoperative menstrual cycle and also blood FSH level was evaluated. The ultrasonography was performed with the use of a $6.5 \mathrm{MHz}(5-7.5 \mathrm{MHz})$ transvaginal microconvex probe by independent examiner, blinded to the clinical and surgical history of the patients. The AFCs of both ovaries were recorded as the total number of follicles with a diameter of 2-9 $\mathrm{mm}$ in each ovary separately postoperatively.

Statistical analysis was performed by using SPSS 15 (SPSS Inc. Chicago, IL). Distributions of variables were analyzed by normality tests. PairedSamples T-test was used to evaluate the difference between the AFC of each ovaries. Preoperative and postoperative levels of FSH were evaluated by Wilcoxon Signed Rank test. Correlation between total AFC and postoperative FSH level was calculated with Spearman's correlation. A p value of $<0.05$ was accepted as statistically significant. 


\section{RESULTS}

The demographic and clinical characteristics of 21 women at the time of surgery were shown in Table 1. All patients were operated due to endometriosis related pain. The mean diameter of endometrioma was $41.6 \pm 18.9 \mathrm{~mm}$.

There was statistically significant difference in the mean number of antral follicles in the operated side ovary $(2.61 \pm 1.24)$ when compared to the non-operated side ovary $(4.23 \pm 0.88)(\mathrm{p}<0.001)$ (Figure 1).

There was also statistically significant difference between pre and postoperative FSH levels $(6.7 \pm 1.8$ vs $6.9 \pm 1.6)(\mathrm{p}=0.013)$ (Figure 2$)$. No correlation was found between total AFC and postoperative FSH level $(\mathrm{r}=-0.24, \mathrm{p}=0,28)$.

TABLE 1: Demographic and clinical characteristics of patients who underwent laparoscopic endometrioma removal.

\begin{tabular}{|lc|}
\hline & N of patients= 21 \\
\hline Age (years, median,25p-75p) & $32(26-35)$ \\
Parity (median,25p-75p) & $1(0-2.5)$ \\
BMI (kg/m²,median,25p-75p) & $22(21-24)$ \\
Previous complaints related to endometriosis $(\mathrm{n}, \%)$ & \\
CPP & $19(90.5)$ \\
Dysmenorrhea & $16(76.2)$ \\
Dyspareunia & $4(19)$ \\
CPP+dysmenorrhea & $16(76.2)$ \\
CPP+dyspareunia & $4(26.7)$ \\
Dysmenorrhea+dyspareunia & $3(20)$ \\
Infertility & $0(0)$ \\
\hline
\end{tabular}

BMI: Body mass index; CPP: Chronic pelvic pain.

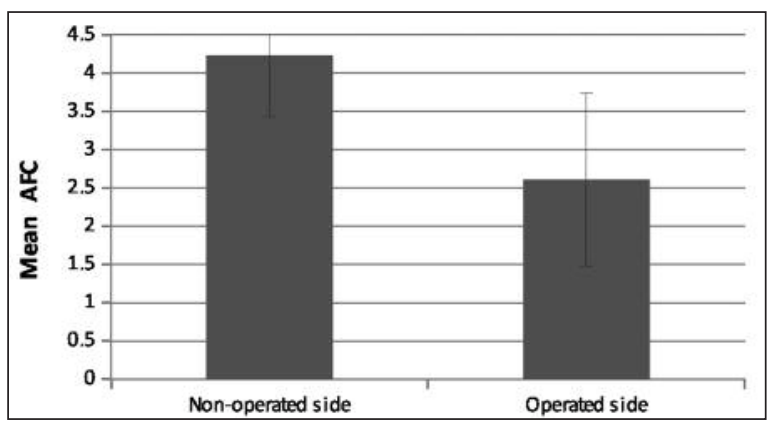

FIGURE 1: Antral follicle count in operated and non operated ovaries.

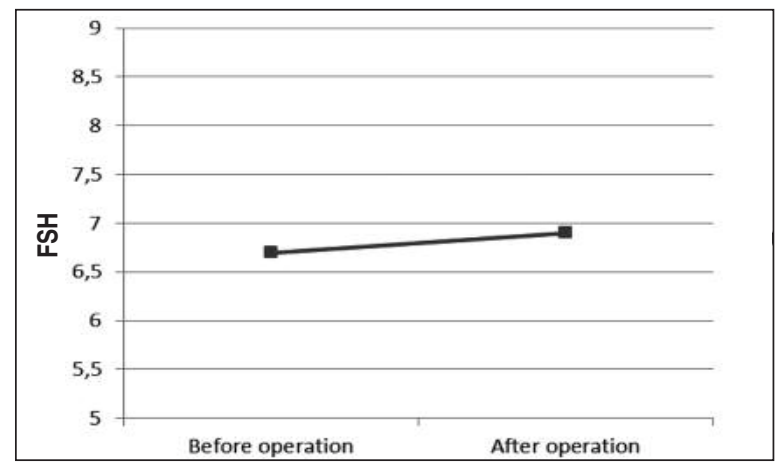

FIGURE 2: Preoperative and postoperative FSH levels.

\section{DISCUSSION}

Studies have demonstrated that; treatment of endometriomas with cyst wall ablation, drainage and coagulation or laser vaporization is associated with higher risk of recurrence than excisional surgery. ${ }^{11-13}$ Laparoscopic cyst excision is considered to be the best treatment because of the lower recurrence and a higher pregnancy rate compared with conservative surgery. ${ }^{11}$ Recent data suggested that excisional surgery of endometriomas, in particular the stripping technique may cause ovarian trauma. ${ }^{10}$ Given the possible mechanism of cortical invagination leading to endometrioma formation, stripping of the cyst capsule may result in inadvertent removal of primordial, preantral and antral follicles from the healthy cortical tissue. This in turn may lead to iatrogenic depletion of ovarian follicles so ovarian reserve. ${ }^{14-16}$

Ovarian reserve can be screened by; age, biochemical tests either static tests as FSH, E2, FSH:LH, inhibin-B, anti-Mullerian hormone or dynamic tests as clomiphene citrate challenge test and gonadotrophin releasing hormone test or biophysical tests as ovarian volume and antral follicle count. ${ }^{17}$

AFC has been strongly associated with the follicle pool and is used as a reliable sonographic indicator of ovarian reserve. ${ }^{18}$ The loss of AFC associated with stripping of endometriomas may be clinically important in infertile patients, especially if they have low ovarian reserve so more careful attention is advised. ${ }^{10}$ In the current study, we used the antral follicle count measured transvaginally 
for the assessment of ovarian reserve and we demonstrated that after cystectomy by laparoscopic stripping technique the mean number of antral follicles was significantly lower in operated side when compared with non-operated side ovary. In a recent randomized study, Var et al. compared the post-operative AFC, ovarian volume and response to ovulation stimulation in patients with bilateral endometriomas treated either by cystectomy or coagulation of cyst capsule with bipolar energy; they found that cystectomy was associated with more damage to the ovaries when assessed for these variables. $^{10}$

It is revealed that; stripping of the cyst wall may result in ovarian reserve damage due to the removal of healthy ovarian cortex and thermal destruction of ovarian follicles by use of bipolar coagulation for bleeding, which commonly applied after stripping. ${ }^{19,20}$ Hemostatic procedure after stripping of endometrioma might be one of the most important step in the operation. Ferrero et al. showed through a randomized controlled trial that laparoscopic stripping of ovarian endometriotic cyst significantly decreases ovarian reserve [measured by means of serum anti Mullerian hormon (AMH) and basal FSH levels] independent from the method used to obtain hemostasis on the ovarian tissue (bipolar coagulation or suturing). ${ }^{21}$ In our study, the suturing technique was used to control bleeding after cystectomy based on this data but postoperative AFC of operated ovaries was shown to be significantly decreased while the postoperative FSH levels were found to be increased.
This findings could not confirm whether the damage of residual ovarian tissue caused by suturing or not. The suture might induce ischemic damage to the ovary. Nevertheless, because the increase in postoperative FSH levels were not clinically important, suturing might contribute to the preservation of ovarian reserve.

One of the limitations of our study was; limited sample of subjects. Sample size could be larger to achieve more reliable results. The other limitations of our study was the measurements of antral follicle count could only be performed after the operation. Endometriosis per se could have detrimental effect on the affected side. Before and after study design would be better to accomplish this limitations. Another limitations was the lack of $\mathrm{AMH}$ measurements before and after the endometrioma surgery. AMH is a more reliable and consistent ovarian reserve marker. Nevertheless our study have the strengths of measuring AFC as the side spesific marker to evaluate the effect of unilateral endometrioma surgery.

In conclusion, our study results based on a limited number of subjects suggested that excision of endometriomas might have a negative impact on ovarian reserve as demonstrated by a significant postoperative fall in ipsilateral AFC in the operated site and increase in blood FSH level. Although this is the technique of choice in terms of pain relief and less recurrence rate in patients with endometrioma the possibility of decrease in ovarian reserve should be taken into account.

\section{REFERENCES}

1. Bulun SE. Endometriosis. Engl J Med 2009; 360(3):268-79.

2. Gupta S, Goldberg JM, Aziz N, Goldberg E, Krajcir N, Agarwal A. Pathogenic mechanisms in endometriosis-associated infertility. Fertil Steril 2008;90(2):247-57.

3. Canis M, Mage G, Wattiez A, Chapron C, Pouly JL, Basil S. Second look laparoscopy after laparoscopic cystectomy of large endometriomas. Fertil Steril 1992;58(3):6179.
4. Jones KD, Sutton CJ. Laparoscopic management of ovarian endometriomas: a critical review of current practice. Curr Opin Obstet Gynecol 2000;12(4):309-15.

5. Hart R, Hickey M, Maouris P, BuckettW, Gary $R$. Excisional surgery versus ablative surgery for ovarian endometrioma: a Cochrane Review. Hum Reprod 2005;20(11):3000-7.

6. Yeung PP Jr, Shwayder J, Pasic RP. Laparoscopic management of endometriosis: comprehensive review of best evidence. J
Minim Invasive Gynecol 2009;16(3):26981.

7. Ho HY, Lee RK, Hwu YM, Lin MH, Su JT, Tsai YC. Poor response of ovaries with endometrioma previously treated with cystectomy to controlled ovarian hyperstimulation. J Assist Reprod Genet 2002;19(11):507-11.

8. Brosens IA, Van Ballaer P, Puttemans P, Deprest $J$. Reconstruction of the ovary containing large endometriomas by an extraovarian endosurgical technique. Fertil Steril 1996;66(4):517-21. 
9. Donnez J, Nisolle M, Gillet N, Smets M, Bassil S, Casanas-Roux F. Large ovarian endometriomas. Hum Reprod 1996;11(3):641-6.

10. Var T, Batioglu S, Tonguc E, Kahyaoglu I. The effect of laparoscopic ovarian cystectomy versus coagulation in bilateral endometriomas on ovarian reserve as determined by antral follicle count and ovarian volume: a prospective randomized study. Fertil Steril 2011;95(7): 2247-50.

11. Beretta P, Franchi M, Ghezzi F, Busacca M, Zupi E, Bolis P. Randomized clinical trial of two laparoscopic treatments of endometriomas: cystectomy versus drainage and coagulation. Fertil Steril 1998;70(6):1176-80.

12. Vercellini $P$, Chapron $C$, DeGiorgi $O$, Consonni D, Frontino G, Crosignani PG. Coagulation or excision of ovarian endometriomas? Am J Obstet Gynecol 2003;188(3):606-10.

13. Busacca M, Marana R, Caruana P, Candiani M, Muzii L, Calia C, et al. Recurrence of ovar- ian endometrioma after laparoscopic excision. Am J Obstet Gynecol 1999;180(3 Pt 1):51923.

14. Busacca M, Vignali M. Endometrioma excision and ovarian reserve: a dangerous relation. $J$ Minim Invasive Gynecol 2009;16(2):142-8.

15. van der Weiden RM. Damage to ovarian reserve associated with laparoscopic excision of endometriomas: a quantitative rather than qualitative injury. Am J Obstet Gynecol 2006; 195(6):1874.

16. Ragni G, Somigliana E, Benedetti F, Paffoni A, Vegetti W, Restelli L, et al. Damage to ovarian reserve associated with laparoscopic excision of endometriomas: a quantitative rather than a qualitative injury. Am J Obstet Gynecol 2005;193(6):1908-14.

17. Jirge PR. Ovarian reserve tests. J Hum Reprod Sci 2011;4(3):108-13.

18. Mattukrishna $S$, McGarrigle H, Wakim R, Khadum I, Ranieri DM, Serhal P. Antral follicle count, antimullerian hormone and inhibin B: predictors of ovarian response in assisted reproductive technology? BJOG 2005;112(10): 1384-90.

19. Somigliana E, Ragni G, Benedetti F, Borroni $R$, Vegetti W, Crosignani PG. Does laparoscopic excision of endometriotic ovarian cysts significantly affect ovarian reserve? Insights from IVF cycles. Hum Reprod 2003;18(11): 2450-3.

20. Hachisuga T, Kawarabayashi T. Histopathological analysis of laparoscopically treated ovarian endometriotic cysts with special reference to loss of follicles. Hum Reprod 2002; 17(2):432-5.

21. Ferrero $S$, Venturini PL, Gillott DJ, Remorgida V, Leone Roberti Maggiore U. Hemostasis by bipolar coagulation versus suture after surgical stripping of bilateral ovarian endometriomas: a randomized controlled trial. J Minim Invasive Gynecol 2012;19(6):722-30. 